\title{
Control Of Peanut Root-Rot Using Some Chemical Substances
}

\author{
Naglaa M. I. Fath ELBabe ${ }^{1,2}$, Abdelnaser A. Elzaawely ${ }^{1 *}$, Saber M. A. Morsy ${ }^{2}$ and \\ Hassan M. El-Zahaby ${ }^{1}$ \\ ${ }^{1 *}$ Department of Agricultural Botany, Faculty of Agriculture, Tanta University, Tanta, \\ ${ }^{2}$ Plant Pathology Research Institute, Agricultural Research Center, Giza, Egypt.
}

\begin{abstract}
$\mathbf{P}$ EANUT (Arachis hypogaea L.) is an important leguminous crop in Egypt. Root rot caused by Rhizoctonia solani is the most common disease of peanuts. In this study, six isolates of $R$. solani were isolated from peanut roots in El-Behera governorate during 2014 and 2015 growing seasons. Humic acid (H), sulfur (S) and gypsum $(\mathrm{G})$ alone or in combinations were used as a seed dressing or a soil application to control root-rot disease in two peanut cultivars (Gregory and Ismailia1). Results indicated that peanut cv. Gregory appeared to be more susceptible to the fungus than cv. Ismailia1. Under greenhouse conditions, the combination of the three substances $(\mathrm{H}+\mathrm{S}+\mathrm{G})$ caused the highest reduction in the incidence of $R$. solani damping-off on peanut cv. Gregory. Similar results were also obtained in the field experiment during 2015 and 2016 growing seasons. Furthermore, the results also indicated that each chemical substances and their combinations improved the growth characters in terms of the root and shoot weight as well as the yield of peanut plants.
\end{abstract}

Keywords: Rhizoctonia solani, Peanut, Damping-off, Root rot.

\section{Introduction}

Peanut (Arachis hypogaea L.) is one of the most important leguminous oil and food crop. High quality seeds are used for industries, while low quality seeds and shoots of harvested plants are used for animal feeding. The cultivated area of groundnuts with shell in Egypt reached 57,321 ha and producing 183,438 tons (FAO, 2014). Most of the peanut cultivation is in infertile soil and usually infested with several plant pathogens. Plant nutrition is crucial in those soils for acceptable and exportable peanut yield. Several soil-borne diseases caused by Fusarium spp., Rhizoctonia solani, Macrophomina phaseolina, Sclerotium rolfsii, Pythium spp. and Aspergillus niger (Helal et al., 1994; Morsy, 1999; Atta-Alla et al., 2004) affect peanut.

Amendment of soil with organic or inorganic chemicals results in better uptake of nutrients by root system that improves crop yield and increases the suppression of root infecting fungi (Rafi et al., 2016). The use of gypsum reduced the incidence of groundnut pod rot and increased the pod yield (Walker and Csinos, 1980; Chen and Huang, 1992; Ismail and Abd-El-Momen, 2007). Humic substances have been proven to improve the soil fertility and increase the availability of nutrients and consequently increase plant growth and yield (Moraditochaee, 2012). It was used to reduce the negative effects of pathogenic fungi such as Fusarium solani on mandarin (El-Mohamedy and Ahmed, 2009) and Fusarium graminearum and Bipolaris sorokiniana on wheat plants (Sakr et al., 2010). The application of sulfur significantly increased potato tuber yield and decreased the infection rate with Rhizoctonia solani (klikocka et al., 2005).

The aim of this investigation was to study the efficacy of sulphur, gypsum and humic acid individually or in combinations for controlling Rhizoctonia solani root rot in peanut.

\section{Materials and Methods}

Isolation and identification of the pathogen A survey of peanut root-rot diseases was carried 
out during the 2014 and 2015 growing seasons in different localities of El-Behera governorate (ElBostan, El-Nobaria, South El-Tahrir and Shabeb El- Khrigine). Collected diseased peanut roots of each locality were washed thoroughly with tap water, and small pieces of the diseased parts were surface sterilized by immersing in 3\% Colorox $(\mathrm{NaOCl})$ solution for three minutes. After rinsing several times in sterilized distilled water, samples were dried between two sterilized filter papers, then placed on PDA medium in Petri-dishes and incubated at $22 \pm 1^{\circ} \mathrm{C}$ for 3 to 7 days. Hyphal tip or single spore of each the developing fungi was transferred to PDA medium. Inoculum of each purified culture was transferred into PDA slants and incubated at 25 ${ }^{\circ} \mathrm{C}$. The developed fungal growth was sub-cultured and identified at the Department of Mycology, Plant Pathology Research Institute, Agricultural Research Center in Egypt according to Hildebrand (1938), Gilman (1957) and Booth (1971). Stock cultures were maintained on PDA slants and kept in a refrigerator at $5^{\circ} \mathrm{C}$ for further studies.

\section{Pathogenicity test}

The pathogenicity of $R$. solani isolates were tested against two cultivars of peanut (Gregory and Ismailia1). Glass bottles containing autoclaved sorghum-coarse sand-water $(2: 1: 2 \mathrm{v} / \mathrm{v} / \mathrm{v})$ medium were inoculated by each isolate using agar dishes taken from the periphery of its 5 days-old colony and incubated at $25{ }^{\circ} \mathrm{C}$ for 10 days. The inoculum were used by disk ( $3 \mathrm{~mm}$ diameter) at the rate of $5 \% \mathrm{w} / \mathrm{w}$, to infest sterilized potted soil, mixed thoroughly with the soil, then watered and left for one week before sowing. Apparently, healthy seeds of peanut Ismailial or Gregory cultivars were surface disinfested by sodium hypochlorite solution (3\%) for $2 \mathrm{~min}$ before sowing. The seeds were sown at the rate of 5 seeds/pot (30 $\mathrm{cm}$ diameter). Four pots were used for each particular treatment. Pots containing sterile non-infested soil were used as a control. Percentage of pre-and post-emergence damping-off were calculated after 30 and 60 days from sowing, respectively (Morsy, 1999).

\section{Greenhouse experiment}

Greenhouse experiment was conducted to evaluate the efficacy of humic acid, sulfur and gypsum, individually or in combinations, on peanut cv. Gregory pre- and post- emergence damping-off in pots during 2015 season. Sterilized potted soil was inculcated with $\mathrm{I}_{6}$ (the most aggressive isolate of $R$. solani) in a barley grains medium at a rate of $5 \mathrm{~g} / \mathrm{kg}$ soil (Morsy, 1999). The soil was then moistened with water for one

Env. Biodiv. Soil Security Vol.1 (2017) week before sowing. Peanut seeds cv. Gregory were surface disinfested by sodium hypochlorite solution (3\%) for $2 \mathrm{~min}$ before sowing.

\section{Preparation of the treatments}

In the seed dressing treatment, gypsum $(10 \mathrm{~g})$, sulfur (5 g) and humic (2 g) were incorporated, separately or in combinations, with $1 \mathrm{~kg}$ seeds before sowing; while in the soil application treatment, the above-mentioned substances were added to each pot. The experiment was carried out in a randomized complete block design with four replicates for each particular treatment. Five seeds were sown in each pot, and four pots filled with non-treated seeds were serve as a control.

\section{Disease assessment}

Disease assessment was recorded as percentage of damping-off (pre- and post-emergence) after 30 days and 60 days from sowing using the following formula (Hussien et al. 2012):

$$
\begin{aligned}
& \% \text { Pre-emergence }=\frac{\text { Number of non germinated seeds }}{\text { Number of sown seeds }} \times 100 \\
& \% \text { Post-emergence }=\frac{\text { Number of dead seedlings }}{\text { Number of sown seeds }} \times 100
\end{aligned}
$$

Effect of treatments on growth characters and yield of peanut plants

Growth characters of peanut plants including fresh weight $(\mathrm{g})$ were recorded in different treatments and control at harvesting time and the average pod yield/plant was calculated in each treatment.

\section{Field experiments}

Field experiments were conducted in two successive seasons (2015 and 2016) at El-Tahrir region in El-Behera governorate to determine the effect of three chemical soil amendments or treated seed as seed dressing on pre- and post-emergence damping-off (determined at 30 and 60 days after sowing by checking each plot) and yield (weight of 100 pods/treatment) of Gregory cultivar. The applied treatments were used individually or in combinations as follows:

(1) Gypsum at one ton/fed in two equal portions. The first one was at soil preparation and the second one was at the beginning of the flowering stage. Seeds were treated with gypsum as seed dressing at the rate of 5 gypsum: $1 \mathrm{~kg}$ seeds.

(2) Sulfur at $500 \mathrm{~kg} / \mathrm{fed}$ was added during soil preparation. Seeds were treated with sulfur at the rate of $5 \mathrm{~g}$ sulfur: $1 \mathrm{~kg}$ seeds. 
(3) Humic acid at $10 \mathrm{~kg} / \mathrm{fed}$ was added during sowing. Seeds were treated with humic acid at the rate of $5 \mathrm{~g}$ humic: $1 \mathrm{~kg}$ seeds.

The experiment was laid out in a factorial design (Snedecor, 1956) in four replicates for each treatment. In the main plots, the cultivar Gregory was randomly distributed, while the three soil amendments or seed dressing were sub-plotted. The control was randomly allotted in sub-plots. The area of each sub-plot was $9 \mathrm{~m}^{2}(3 \mathrm{~m} \times 3 \mathrm{~m})$ and consisted of three rows $5 \mathrm{~m}$ long and $0.75 \mathrm{~m}$ apart and hill spacing at $10 \mathrm{~cm}$ single seed was sown in each hill. The preceding crop was potatoes in both seasons. Seeds of peanut were sown on $25^{\text {th }}$ and $26^{\text {th }}$ of May 2015 and 2016, respectively. Weed control was non-treated. Irrigation was applied every three days using sprinkler irrigation system. Other agricultural practices for peanut production were applied according to the recommendations.

\section{Statistical analysis}

The collected data were statically analyzed as described by Gomez and Gomez (1984). The new least significant difference was used to compare the differences among means (SAS, 1996).

\section{$\underline{\text { Results and Discussion }}$}

Pathogenicity test of $R$. solni

Six isolates of $R$. solni were collected and isolated from different localities of El-Behera Governorate. All obtained fungal isolates proved to be able to infect peanut plants causing root rot symptoms. According to the results presented in Table 1, isolate No. $6\left(\mathrm{I}_{6}\right)$ was the most pathogenic as incited pre-emergence damping-off $40 \%$ and $45 \%$ and so post-emergence damping-off $25 \%$ and $30 \%$ on the tested peanut cultivars Ismailia 1 and Gregory, respectively. However, isolate No. $3\left(\mathrm{I}_{3}\right)$ was the least pathogenic recorded $15 \%$ and $20 \%$ for pre-emergence as well as $10 \%$ and $10 \%$ for post-emergence on two cultivars, respectively. On the other hand, results in Table (1) also indicated that peanut cv. Gregory was more susceptible than Ismailia 1 was. Accordingly, isolate $\mathrm{I}_{6}$ and Gregory cultivar were selected for further experiments. $R$. solani is considered one of the most destructive fungi to peanut plant causing pre-and post-emergence damping-off and pod necrosis. The same trend was found by Ibrahim et al (1977) and Morsy (1999 and 2013).

Effect of soil application or seed dressing by some chemical substances on percentage of preand post-emergence damping-off on peanut $\mathrm{cv}$.

\section{Gregory}

\section{Under greenhouse condition}

The ability of the three chemical substances, alone or in combinations, to control $R$. solani were evaluated under greenhouse conditions. Results in Table 2 indicated that, disease incidence was significantly reduced in all treatments in comparison with the control. The best reduction in damping-off disease incidence was noted when peanut seeds were treated with chemical substances as a combination (Humic + Sulphur + Gypsum) in case of soil application or seed dressing, as the average reduction reaches to $12.5 \%$ and $2.5 \%$ compared with $50 \%$ and $25 \%$ for the control, respectively. Furthermore, the seed dressing with chemical substances was appeared to be better than soil application for controlling the disease in all treatments.

Results in Tables 3-5 indicated that significant differences were found in the root and shoot fresh weights and number of pods/plant of peanut plants. The highest means of root and shoot fresh weights as well as number of pods/plant (16 g, 35 $\mathrm{g}$ and $14 \mathrm{pod} /$ plant, respectively) were obtained when chemical substances (Humic + Sulphur + Gypsum) were used as a combination applied as a soil application and a seed dressing. However, sulfur alone obtained lower root weight $(11.4 \mathrm{~g} /$ plant) and $8.5 \mathrm{pod} / \mathrm{plant}$; while shoot weight reached to $23.65 \mathrm{~g} / \mathrm{plant}$ when humic acid was used alone (Table 3 ). This could be due to the utilization of various chemical substances. These results are in agreement with those of Hussein et al. (2000) and Ismail and Abd El-Momen (2007).

\section{Under field condition}

The three chemical substances alone or in combinations under field condition had similar effect to that obtained under greenhouse in reducing the damping-off. Results in Table 6 indicated that all soil application or seed dressing had significantly positive effect in reducing disease incidence in growing seasons 2015 and 2016. Treatment of the combination of humic, sulfur and gypsum was the most effective to reduce damping-off reaching to $7.5 \%$ and $3.75 \%$ in case of seed dressing and soil application, respectively for 2015 season; and $7.0 \%$ and $7.0 \%$ in case of seed dressing and soil application, respectively for 2016 season. However, the mean percentage of damping-off in the control reaches to $41.0 \%$ and $28.0 \%$ as seed dressing and soil application, respectively in the 2015 season, while it reaches 
TABLE 1. Pre- and post-emergence damping off incited on Ismailia1 and Gregory cultivars of peanut sown in potted soil artificially infested with Rhizoctoniasolani isolates.

\begin{tabular}{|c|c|c|c|c|c|c|c|}
\hline \multirow{3}{*}{ Isolates } & \multicolumn{7}{|c|}{ \%Damping- off } \\
\hline & \multicolumn{3}{|c|}{ Pre-emergence } & \multicolumn{3}{|c|}{ Post-emergence } & \multirow[b]{2}{*}{ I Mean } \\
\hline & Ismailia1 & Gregory & Mean & Ismailia1 & Gregory & Mean & \\
\hline Control & $0.00 \pm 0.00$ & $0.00 \pm 0.00$ & $0.00 \pm 0.00$ & $0.00 \pm 0.00$ & $0.00 \pm 0.00$ & $0.00 \pm 0.00$ & $0.00 \pm 0.00 \mathrm{f}$ \\
\hline$I_{1}$ & $25.00 \pm 4.08$ & $30.00 \pm 4.90$ & $27.50 \pm 4.49$ & $10.00 \pm 1.63$ & $20.00 \pm 3.27$ & $15.00 \pm 2.45$ & $21.25 \pm 3.47 \mathrm{c}$ \\
\hline $\mathbf{I}_{2}$ & $20.00 \pm 3.27$ & $35.00 \pm 5.72$ & $27.50 \pm 4.49$ & $20.00 \pm 3.27$ & $15.00 \pm 2.45$ & $17.50 \pm 2.86$ & $22.50 \pm 3.68 \mathrm{~b}$ \\
\hline $\mathbf{I}_{3}$ & $15.00 \pm 2.45$ & $20.00 \pm 3.27$ & $17.50 \pm 2.86$ & $10.00 \pm 1.63$ & $10.00 \pm 1.63$ & $10.00 \pm 1.63$ & $13.75 \pm 2.25 \mathrm{e}$ \\
\hline $\mathrm{I}_{4}$ & $25.00 \pm 4.08$ & $30.00 \pm 4.90$ & $27.50 \pm 4.49$ & $15.00 \pm 2.45$ & $20.00 \pm 3.27$ & $17.50 \pm 2.86$ & $22.50 \pm 3.68 \mathrm{~b}$ \\
\hline$I_{5}$ & $25.00 \pm 4.08$ & $20.00 \pm 3.27$ & $22.50 \pm 3.68$ & $10.00 \pm 1.63$ & $20.00 \pm 3.27$ & $15.00 \pm 2.45$ & $18.75 \pm 3.06 \mathrm{~d}$ \\
\hline $\mathbf{I}_{6}$ & $40.00 \pm 6.53$ & $45.00 \pm 7.35$ & $42.50 \pm 6.94$ & $25.00 \pm 4.08$ & $30.00 \pm 4.90$ & $27.50 \pm 4.49$ & $35.00 \pm 5.72 \mathrm{a}$ \\
\hline C Mean & Ismailia1 & $17.14 \pm 2.80 \mathrm{~b}$ & \multicolumn{4}{|c|}{$\begin{array}{ll}\text { Gregory } & 21.07 \pm 3.44 \text { a } \\
\end{array}$} & \\
\hline T mean & $\begin{array}{c}\text { Pre- } \\
\text { emergence }\end{array}$ & $23.57 \pm 3.85$ a & $\begin{array}{c}\text { Post- } \\
\text { emergence }\end{array}$ & \multicolumn{2}{|c|}{$14.64 \pm 2.39 \mathrm{~b}$} & & \\
\hline L.S.D (0.05) & \multirow{2}{*}{\multicolumn{6}{|c|}{0.57}} & \\
\hline I & & & & & & & \\
\hline $\mathbf{T}$ & \multicolumn{6}{|c|}{0.30} & \\
\hline C & \multicolumn{6}{|c|}{0.30} & \\
\hline $\mathbf{I} \times \mathbf{C}$ & \multicolumn{6}{|c|}{0.68} & \\
\hline $\mathbf{I} \times \mathbf{T}$ & \multicolumn{6}{|c|}{0.68} & \\
\hline $\mathbf{C} \times \mathbf{T}$ & \multicolumn{6}{|c|}{0.36} & \\
\hline $\mathbf{I} \times \mathbf{T} \times \mathbf{C}$ & \multicolumn{6}{|c|}{0.96} & \\
\hline
\end{tabular}

- Values are means of four replicates in each treatment \pm SE.

- Means values in each column followed by the same letter are not significantly different $(\mathrm{P} \leq 0.05)$.

- I: Isolate,T: Time, C: Cultivar.

TABLE 2. Effect of some chemical substances on damping-off of peanut cv. Gregorycaused by R.solani under greenhouse condition.

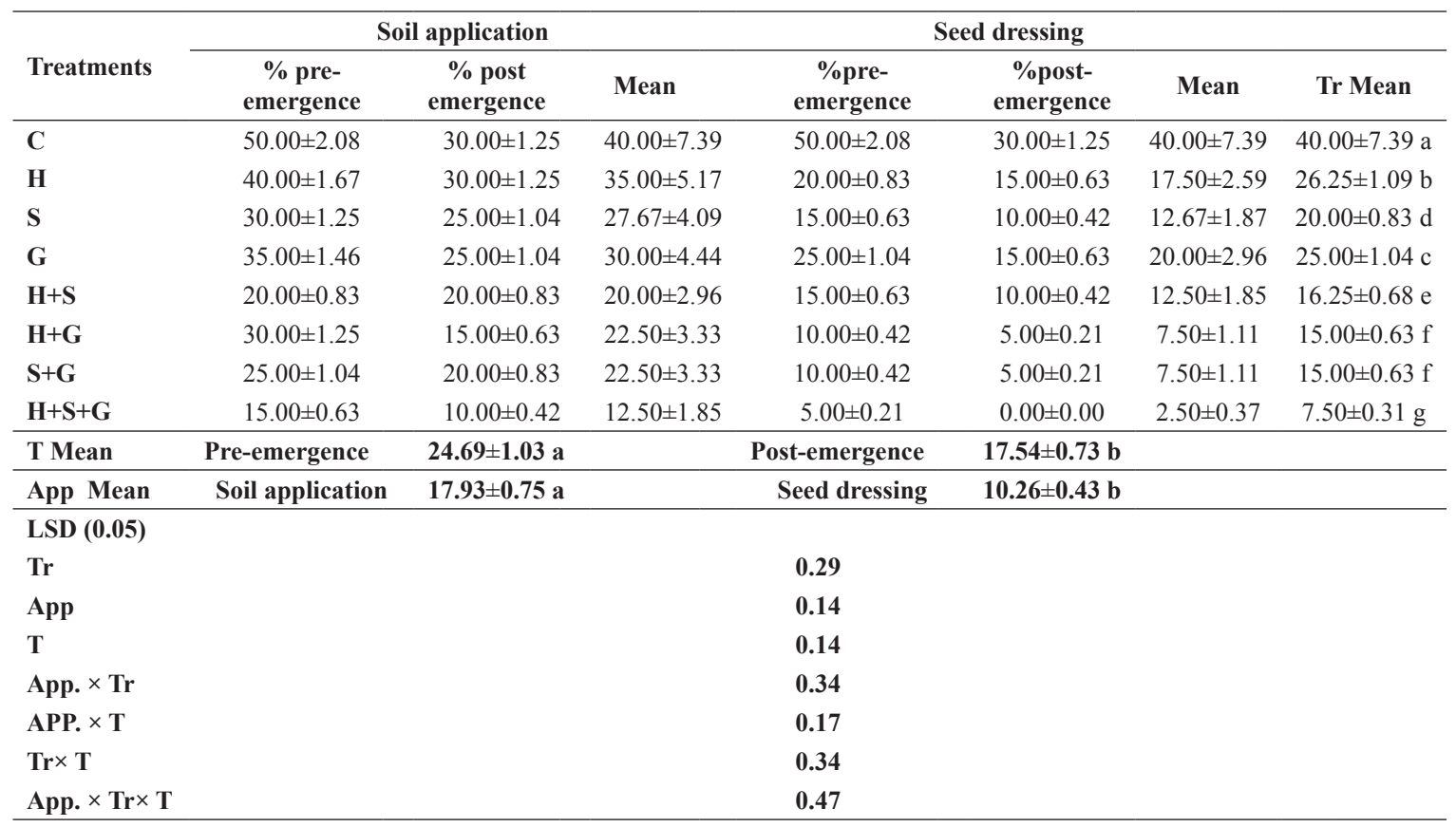

- Values are means of four replicates in each treatment \pm SE.

- Means values in columns followed by the same letter are not significantly different $(\mathrm{P} \leq 0.05)$.

- C: Control, H: Humic acid, S: Sulphur, G: Gypsum, H+S: Humic acid+Sulphur, H+G: Humic acid+Gypsum, S+G:Sulphur+Gypsum, $\mathrm{H}+\mathrm{S}+\mathrm{G}$ : Humic acid+Sulphur+Gypsum, Tr: Treatment, T: Time, App: Application. 
TABLE 3. Effect of some chemical substances on root weight (g/plant) of peanut cv. Gregoryunder greenhouse conditions.

\begin{tabular}{lccc}
\hline \multirow{2}{*}{ Treatments } & \multicolumn{3}{c}{ Root weight(g/plant) } \\
\cline { 2 - 4 } & Soil application & Seed dressing & Mean \\
\hline C & $9.30 \pm 0.12$ & $9.30 \pm 0.12$ & $9.30 \pm 0.12 \mathrm{~g}$ \\
H & $10.60 \pm 0.13$ & $12.80 \pm 0.16$ & $11.70 \pm 0.15 \mathrm{e}$ \\
S & $11.30 \pm 0.14$ & $11.50 \pm 0.15$ & $11.40 \pm 0.14 \mathrm{f}$ \\
G & $12.80 \pm 0.16$ & $14.50 \pm 0.18$ & $14.45 \pm 0.17 \mathrm{c}$ \\
H+S & $15.20 \pm 0.19$ & $13.70 \pm 0.17$ & $\mathrm{~b}$ \\
H+G & $12.80 \pm 0.16$ & $13.60 \pm 0.17$ & $13.20 \pm 0.17 \mathrm{~d}$ \\
S+G & $14.00 \pm 0.18$ & $15.30 \pm 0.19$ & $14.65 \pm 0.19 \mathrm{~b}$ \\
H+S+G & $16.10 \pm 0.20$ & $15.90 \pm 0.20$ & $16.00 \pm 0.20 \mathrm{a}$ \\
\hline App Mean & & & \\
\hline L.S.D (0.05) & $\mathbf{1 2 . 7 6 \pm 0 . 1 6 ~ b}$ & $\mathbf{0 . 2 3}$ & $\mathbf{0 . 1 2}$ \\
Tr & & $\mathbf{0 . 2 9}$ & $\mathbf{0 . 1 7}$ \\
App & & & \\
Tr $\times$ App & & & \\
\hline
\end{tabular}

-Means values in columns followed by the same letter are not significantly different $(\mathrm{P} \leq 0.05)$.

-C: Control, H: Humic acid, S: Sulphur, G: Gypsum, H+S: Humic acid+Sulphur, H+G: Humic acid+Gypsum, S+G: Sulphur+Gypsum, $\mathrm{H}+\mathrm{S}+\mathrm{G}$ : Humic acid+Sulphur+Gypsum, App: Application, Tr: Treatment..

TABLE 4. Effect of some chemical substances on shoot weight (g/plant) of peanut cv. Gregoryunder greenhouse conditions.

\begin{tabular}{|c|c|c|c|}
\hline \multirow[t]{2}{*}{ Treatments } & \multicolumn{3}{|c|}{ Shoot weight (g/plant) } \\
\hline & Soil application & Seed dressing & Mean \\
\hline $\mathrm{C}$ & $18.90 \pm 0.63$ & $18.90 \pm 0.63$ & $18.90 \pm 0.63 \mathrm{~h}$ \\
\hline $\mathbf{H}$ & $23.70 \pm 0.79$ & $23.60 \pm 0.79$ & $23.65 \pm 0.79 \mathrm{~g}$ \\
\hline $\mathbf{S}$ & $21.00 \pm 0.70$ & $28.30 \pm 0.94$ & $24.65 \pm 0.82 \mathrm{f}$ \\
\hline G & $25.20 \pm 0.84$ & $26.80 \pm 0.89$ & $26.00 \pm 0.87 \mathrm{e}$ \\
\hline $\mathbf{H}+\mathbf{S}$ & $26.40 \pm 0.88$ & $28.20 \pm 0.94$ & $27.30 \pm 0.91 \mathrm{~d}$ \\
\hline $\mathbf{H}+\mathbf{G}$ & $30.80 \pm 1.03$ & $29.80 \pm 0.99$ & $30.30 \pm 1.01 \mathrm{~b}$ \\
\hline $\mathbf{S}+\mathbf{G}$ & $28.60 \pm 0.95$ & $27.10 \pm 0.90$ & $27.85 \pm 0.93 \mathrm{c}$ \\
\hline $\mathbf{H}+\mathbf{S}+\mathbf{G}$ & $33.30 \pm 1.11$ & $36.70 \pm 1.22$ & $35.00 \pm 1.17 \mathrm{a}$ \\
\hline App Mean & $25.99 \pm 0.87 \mathrm{~b}$ & $27.43 \pm 0.91 \mathrm{a}$ & \\
\hline \multicolumn{4}{|l|}{ L.S.D (0.05) } \\
\hline $\mathbf{T r}$ & & 0.38 & \\
\hline App & & 0.23 & \\
\hline $\mathbf{T r} \times \mathbf{A p p}$ & & 0.47 & \\
\hline
\end{tabular}

-Means values in columns followed by the same letter are not significantly different $(\mathrm{P} \leq 0.05)$.

-C: Control, H: Humic acid, S: Sulphur, G: Gypsum, H+S: Humic acid+Sulphur, H+G: Humic acid+Gypsum, S+G: Sulphur+Gypsum, $\mathrm{H}+\mathrm{S}+\mathrm{G}$ : Humic acid+Sulphur+Gypsum, App: Application, Tr: Treatment.

TABLE 5. Effect of some chemical substances on number of pods/plant of peanut cv. Gregoryunder greenhouse conditions.

\begin{tabular}{|c|c|c|c|}
\hline \multirow{2}{*}{ Treatments } & \multicolumn{3}{|c|}{ Number of pods/plant } \\
\hline & Soil application & Seed dressing & Mean \\
\hline $\mathbf{C}$ & $8.00 \pm 0.32$ & $8.00 \pm 0.32$ & $8.00 \pm 0.32 \mathrm{e}$ \\
\hline $\mathbf{H}$ & $10.00 \pm 0.40$ & $12.00 \pm 0.48$ & $11.00 \pm 0.44 \mathrm{c}$ \\
\hline $\mathbf{S}$ & $9.00 \pm 0.36$ & $8.00 \pm 0.32$ & $8.50 \pm 0.34 \mathrm{e}$ \\
\hline G & $10.00 \pm 0.40$ & $13.00 \pm 0.52$ & $11.50 \pm 0.46 \mathrm{c}$ \\
\hline $\mathbf{H}+\mathbf{S}$ & $11.00 \pm 0.44$ & $11.00 \pm 0.44$ & $11.00 \pm 0.44 \mathrm{c}$ \\
\hline $\mathbf{H}+\mathbf{G}$ & $10.00 \pm 0.40$ & $14.00 \pm 0.56$ & $12.00 \pm 0.48 \mathrm{~b}$ \\
\hline $\mathbf{S}+\mathbf{G}$ & $10.00 \pm 0.40$ & $12.00 \pm 0.48$ & $11.00 \pm 0.44 \mathrm{c}$ \\
\hline $\mathbf{H}+\mathbf{S}+\mathbf{G}$ & $13.00 \pm 0.52$ & $15.00 \pm 0.60$ & $14.00 \pm 0.56 \mathrm{a}$ \\
\hline App. mean & $10.13 \pm 0.41 \mathrm{~b}$ & $11.63 \pm 0.47 \mathrm{a}$ & \\
\hline \multicolumn{4}{|l|}{ L.S.D (0.05) } \\
\hline $\operatorname{Tr}$ & & 0.41 & \\
\hline App & & 0.21 & \\
\hline $\operatorname{Tr} \times \mathbf{A p p}$ & & 0.51 & \\
\hline
\end{tabular}


TABLE 6. Effect of some chemical substances on damping-off of peanut cv. Gregory under field conditions.

\begin{tabular}{|c|c|c|c|c|c|c|c|c|c|}
\hline \multirow{3}{*}{ Treatment } & \multicolumn{4}{|c|}{ Seed dressing } & \multicolumn{4}{|c|}{ Soil application } & \multirow{3}{*}{ Tr. Mean } \\
\hline & \multicolumn{2}{|c|}{2015} & \multicolumn{2}{|c|}{2016} & \multicolumn{2}{|c|}{2015} & \multicolumn{2}{|c|}{2016} & \\
\hline & $\begin{array}{c}\text { \%Pre- } \\
\text { emergence }\end{array}$ & $\begin{array}{c}\text { \%Post- } \\
\text { emergence }\end{array}$ & $\begin{array}{c}\text { \%Pre- } \\
\text { emergence }\end{array}$ & $\begin{array}{c}\text { \%Post- } \\
\text { emergence }\end{array}$ & $\begin{array}{c}\text { \%Pre- } \\
\text { emergence }\end{array}$ & $\begin{array}{c}\begin{array}{c}\text { \%Post- } \\
\text { emergence }\end{array}\end{array}$ & $\begin{array}{c}\text { \%Pre- } \\
\text { emergence }\end{array}$ & $\begin{array}{c}\text { \%Post- } \\
\text { emergence }\end{array}$ & \\
\hline C & $40.00 \pm 2.01$ & $35.00 \pm 1.76$ & $42.00 \pm 2.11$ & $30.00 \pm 1.51$ & $40.00 \pm 2.01$ & $35.00 \pm 1.76$ & $42.00 \pm 2.11$ & $30.00 \pm 1.51$ & $36.75 \pm 1.85 \mathrm{a}$ \\
\hline $\mathbf{H}$ & $27.00 \pm 1.36$ & $20.00 \pm 1.01$ & $28.50 \pm 1.43$ & $9.50 \pm 0.48$ & $12.50 \pm 0.63$ & $7.25 \pm 0.36$ & $19.00 \pm 0.96$ & $10.00 \pm 0.50$ & $16.72 \pm 0.84 \mathrm{c}$ \\
\hline $\mathbf{S}$ & $18.00 \pm 0.91$ & $10.00 \pm 0.50$ & $17.00 \pm 0.86$ & $7.00 \pm 0.35$ & $8.50 \pm 0.43$ & $3.50 \pm 0.18$ & $12.00 \pm 0.60$ & $10.00 \pm 0.50$ & $10.75 \pm 0.54 \mathrm{e}$ \\
\hline G & $30.00 \pm 1.51$ & $14.00 \pm 0.70$ & $26.50 \pm 1.33$ & $17.50 \pm 0.88$ & $15.50 \pm 0.78$ & $6.50 \pm 0.33$ & $22.50 \pm 1.13$ & $15.50 \pm 0.78$ & $18.50 \pm 0.93 \mathrm{~b}$ \\
\hline $\mathbf{H}+\mathbf{S}$ & $13.00 \pm 0.65$ & $6.00 \pm 0.30$ & $16.00 \pm 0.81$ & $6.00 \pm 0.30$ & $7.00 \pm 0.35$ & $4.00 \pm 0.20$ & $13.00 \pm 0.65$ & $7.00 \pm 0.35$ & $9.00 \pm 0.45 \mathrm{f}$ \\
\hline $\mathbf{H}+\mathbf{G}$ & $20.00 \pm 1.01$ & $8.50 \pm 0.43$ & $19.00 \pm 0.96$ & $7.00 \pm 0.35$ & $8.50 \pm 0.43$ & $5.00 \pm 0.25$ & $16.50 \pm 0.83$ & $8.50 \pm 0.43$ & $11.63 \pm 0.59 \mathrm{~d}$ \\
\hline $\mathbf{S}+\mathbf{G}$ & $18.50 \pm 0.93$ & $6.50 \pm 0.33$ & $17.50 \pm 0.88$ & $6.50 \pm 0.33$ & $8.00 \pm 0.40$ & $4.00 \pm 0.20$ & $19.00 \pm 0.96$ & $12.00 \pm 0.60$ & $11.50 \pm 0.58 \mathrm{~d}$ \\
\hline $\mathbf{H}+\mathbf{S}+\mathbf{G}$ & $10.00 \pm 0.50$ & $5.00 \pm 0.25$ & $10.50 \pm 0.53$ & $4.00 \pm 0.20$ & $4.00 \pm 0.20$ & $3.50 \pm 0.18$ & $10.50 \pm 0.53$ & $3.50 \pm 0.18$ & $6.38 \pm 0.32 \mathrm{~g}$ \\
\hline App Mean & Seed dressing & $17.11 \pm 0$ & & Soil application & $13.24 \pm 0$. & & & & \\
\hline S Mean & 2015 season & $14.22 \pm 0$ & & 2016 season & $16.14 \pm 0$. & & & & \\
\hline T Mean & Pre-emergence & $19.15 \pm 0$ & & Post-emergence & $11.18 \pm 0$. & & & & \\
\hline \multicolumn{10}{|l|}{ LSD (0.05) } \\
\hline $\operatorname{Tr}$ & & & & & 0.22 & & & & \\
\hline App & & & & & 0.11 & & & & \\
\hline $\mathbf{S}$ & & & & & 0.11 & & & & \\
\hline $\mathbf{T}$ & & & & & 0.11 & & & & \\
\hline $\operatorname{Tr} \times A p p$ & & & & & 0.16 & & & & \\
\hline $\operatorname{Tr} \times \mathbf{S}$ & & & & & 0.16 & & & & \\
\hline $\operatorname{Tr} \times \mathbf{T}$ & & & & & 0.16 & & & & \\
\hline App $\times$ S & & & & & 0.06 & & & & \\
\hline App $\times \mathbf{T}$ & & & & & 0.06 & & & & \\
\hline $\mathbf{S} \times \mathbf{T}$ & & & & & 0.06 & & & & \\
\hline $\operatorname{Tr} \times \mathbf{a p p} \times \mathbf{S}$ & & & & & 0.23 & & & & \\
\hline $\operatorname{Tr} \times$ app $\times \mathbf{T}$ & & & & & 0.23 & & & & \\
\hline App $\times \mathbf{S} \times \mathbf{T}$ & & & & & 0.11 & & & & \\
\hline $\mathbf{T r} \times \mathbf{A p p} \times \mathbf{S} \times \mathbf{T}$ & & & & & 0.32 & & & & \\
\hline
\end{tabular}

-Values are means of four replicates in each treatment $\pm \mathrm{SE}$.

-Means values in columns followed by the same letter are not significantly different $(\mathrm{P} \leq 0.05)$.

-C: Control, H: Humic acid, S: Sulphur, G: Gypsum, H+S: Humic acid+Sulphur, H+G: Humic acid+Gypsum, S+G: Sulphur+Gypsum, $\mathrm{H}+\mathrm{S}+\mathrm{G}$ : Humic acid+Sulphur+Gypsum, Tr: Treatment, App: Application, S: Season, T: Time.

$36.0 \%$ and $33.0 \%$ for seed dressing and soil application, respectively in 2016 growing season.

Significant differences were found for the weight of 100 pods/treatment $(\mathrm{kg})$ in both growing seasons 2015 and 2016 (Table 7). The combination of humic, sulfur and gypsum exhibited the highest weight of 100 pods with values of $0.403 \mathrm{~kg}$ and $0.403 \mathrm{~kg}$ for soil amended and seed dressing, respectively followed by humic and gypsum with 0.388 and $0.379 \mathrm{~kg}$, respectively. Contrarily, the non-treated control gave the lowest values for the weight of 100 pods exhibiting 0.285 and $0.293 \mathrm{~kg}$ for soil amended and seed dressing, respectively. These results are in accordance to those obtained by Chitkala and Reddy (1991), Ahmed and Osman (2003) and Kalaiyarasan et al. (2003).

Humic substances are mixtures of highmolecular organic compounds. They are created by natural processes in soil organic matter. The formation of defined humic substances depends on chemical soil properties that are determined by a parent material character, the soil forming process, direction, and climate. Humic substances have specific chemical structure and contain various functional groups that determine the role of the humus in the environment (Tolpa et al., 1976). Thus, humic substances also influence the growth of plants including their germination and nourishment on the presence of microorganisms especially the phytopathogenic ones (Tolpa et al., 1976; Abdel-Monaim et al., 2011 and AbdelKader et al., 2012).

Sulfur is a constituent of amino acids, such as cysteine and methionine. Thiamine, biotin, ferredoxines and coenzyme A are examples of $\mathrm{S}$ compounds. Protein also contains $\mathrm{N}$ and $\mathrm{S}$. Therefore, $\mathrm{S}$ deficiency in plants results in lower contents of essential proteins and carbohydrate. 
TABLE 7. Effect of some chemical substances on yield of peanut cv. Gregory under field conditions.

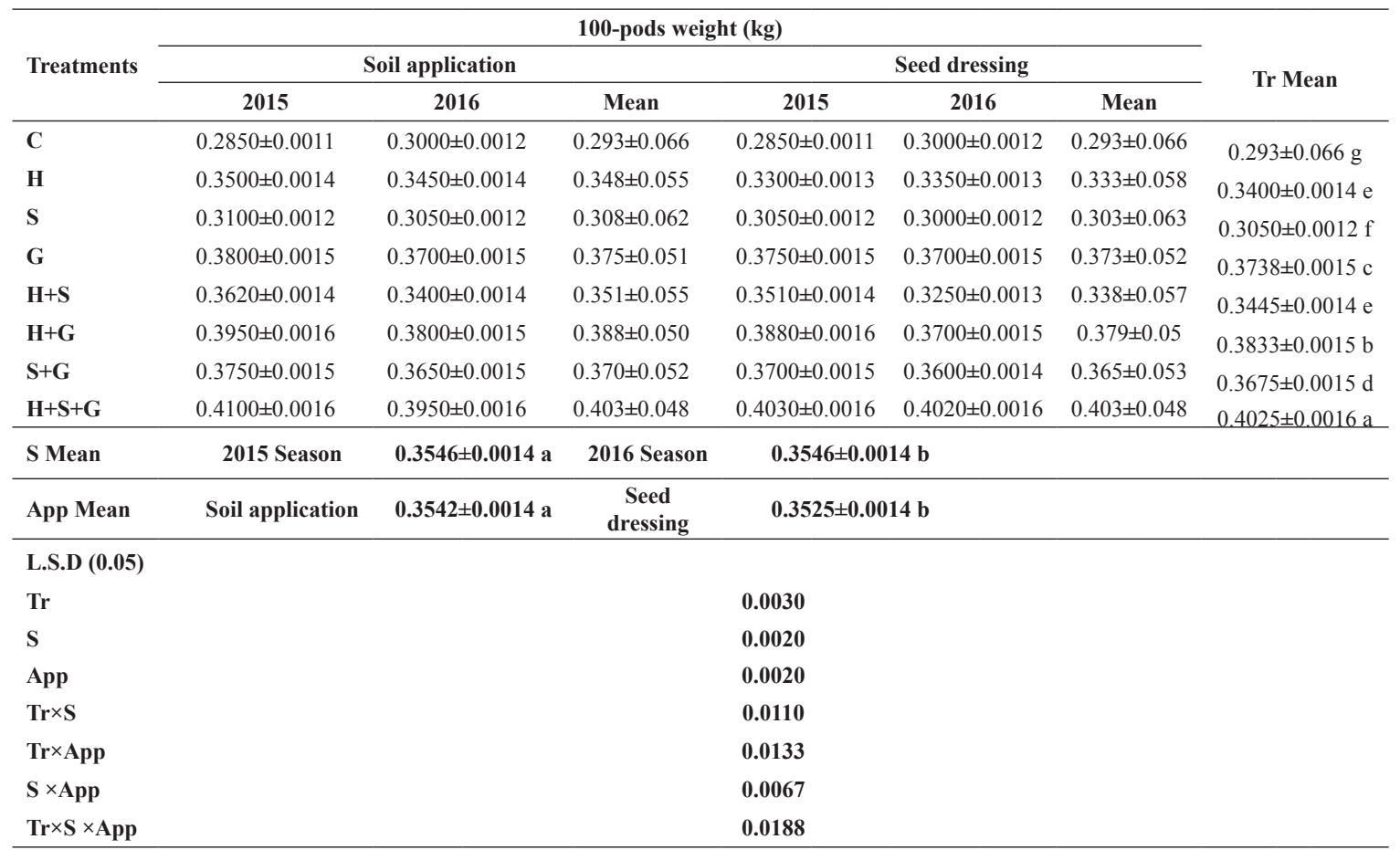

-Values are means of four replicates in each treatment \pm SE.

-Means values in columns followed by the same letter are not significantly different $(\mathrm{P} \leq 0.05)$.

-C: Control, H: Humic acid, S: Sulphur, G: Gypsum, H+S: Humic acid+Sulphur, H+G: Humic acid+Gypsum, S+G: Sulphur+Gypsum, H+S+G: Humic acid+Sulphur+Gypsum, Tr: Treatment, App: Application, S: Season.

Sulfur mainly comes from organic sources and acts as natural biocide as well as increases resistance of plants against pathogens. However, sulfur application significantly influenced the growth, yield attributing characters, yield and oil content over control regardless of the sources and levels of sulfur (Rao et al., 2013).

In addition, results of the current study could be attributed to the role of calcium in building the cell walls of the plant tissues through the formation of calcium pectate, which is more resistant to pectic enzymes, which play an important role in pathogenesis. This finding is consistent with that of Chen and Huang (1992), who reported that the addition of gypsum reduced pod rots and improved the appearance and quality of peanut pods and thus its commercial value. Ismail and Abd El-Momen (2007) also obtained similar results.

\section{Conclusions}

Using the chemical substances (humic, sulfur and gypsum) as a combination in the form of a seed dressing or a soil application gave the highest reduction of $R$. solani incidence, damping-off on peanut cv. Gregory. Furthermore, seed dressing with these chemical substances was better form than the soil application in all treatments. Our results also indicated that these chemical substances was reflected in improving the growth characters in terms of the root and shoot weight as well increasing the pod yield as the number of pods/plant.

\section{References}

Abdel-Kader, M.M., El-Mougy, N.S., Aly, M.D.E., Lashin, S.M. and El-Mohamady, R.S. (2012). Soil drench with fungicides alternatives against root-rot incidence of some vegetables under greenhouse conditions. Int. J. Agric. Forestry, 2, 61- 69.

Abdel-Monaim, M.F., Ismail, M.E. and Morsy, K.M. (2011). Induction of systemic resistance of benzthiadiazole and humic acid in soybean plants against Fusarium wilt disease. Mycobiol., 39, 290-298.

Ahmed, A.A.A. and Osman, E.B.A. (2003). Response of peanut plants grown on a sandy calcareous soil to fertilization with farmyard manure and an organomieral fertilizer prepared from some sugar cane wastes. Assiut J. Agric. Sci., 34, 337-347. 
Atta-Alla, S.I., El-Samra, I.A., El-Korany, A.E., El-Sheikh, M.A. and El-Nawam, M.F. (2004). Management of the root-rot of peanut in the newly reclaimed land in El-Behera Governorate, Egypt. $J$. Agric. Env. Sci. Alex. Univ., 3, 9-26.

Booth, C. (1971). The genus Fusarium. Commonwealth Mycological Institute, Kew, Surrey, England. pp. 237.

Chen, S.S. and Huang, I.W. (1992). Control of pod rot disease of peanut (Arachis hypogaea L.) by soil amendments. I. Effects on pod rot diseases and yield. J. Agric. Forestry, 4, 77-83.

Chitkala, T.D. and Raddy, M.G.R. (1991). Effect of sulfur on growth, yield and oil outturn in groundnut. Ind. J . Agron., 36, 265-266.

El-Mohamedy, R.S.R. and Ahmed, M.A. (2009). Effect of biofertilizers and humic acid on control of dry root rot disease and improvement yield quality of mandarin (Citrus reticulate Blanco). Res. J. Agric. Biol. Sci., 5, 127-137.

FAO. (2014). Food and Agriculture Organization of the United Nations, FAOSTAT Agriculture Data. http://www.fao.org/faostat/en/\#data/QC (accessed August 21, 2017).

Gilman, J. C. (1957). A Manual Of Soil Fungi. Iowa State College Press, U. S. A., pp. 450.

Gomez, K.A. and Gomez, A.A. (1984). Statistical Procedures For Agricultural Research. New York. John Wiley and Sons. Inter. Sci. Pub, (Second Ed.), 423-457.

Helal, A.A., Metwally, A.H., Khaled, S.A. and El-Deeb, A.A. (1994). Evaluation of peanut cultivars, date sowing and NPK as integrated control measures against soil borne diseases. Zagazig J. Agric. Res., 21, 1151-1162.

Hildebrand, E.M. (1938). Techniques for the isolation of single microorganisms. Bot. Rev., 4, 628-658.

Hussein, S.M.A., El-Melegy, A.M. and Haikel, M.A. (2000). Effect of nitrogen frequency, gypsum application, plant density and their interaction on growth and yield of peanut under drip irrigation system in north Sinai. J. Agric. Sci. Mansoura Univ., 25, 2427-2438.

Hussien, Z.N., Mahmoud, Metwaly, E.Y.A.H. and Sobhy, H.M. (2012). Effect of some antagonistic bacteria in reducing of peanut damping-off, root and pod rot incidence caused by Rhizoctonia solani. J. Plant Prot. Path. Mansoura Univ., 3, 1173-1187.
Ibrahim, A.N., Abdou, Y.A. and Abdelal, H.R. (1977). Fungi associated with seedling and pod-rot of peanut in Egypt. Acta Agron. Acad. Sci. Hung., 26, 290-295.

Ismail, F.M. and Abd El-Momen, S.M. (2007). Effect of some soil amendments on yield and disease incidence in peanut (Arachis hypogaea L.). Egypt. J. Agric. Res., 85, 379-398.

Kalaiyarsan, C., Valyapuri, V. and Chandrasekharan, M.V.S. (2003). Effect of sulfur sources and levels on the nutrient up take, crop quality and sulfur use efficiency in groundnut. Ann. Agric. Res. New Series, 24, 478-480.

Klikocka, H., Haneklaus, S., Bloem, E. and Schnug, E. (2005). Influence of sulfur fertilization on infection of potato tubers with Rhizoctonia solani and Streptomyces scabies. J. Plant Nut., 28, 819-833.

Moraditochaee, M. (2012). Effects of humic acid foliar spraying and nitrogen fertilizer management on yield of peanut (Arachis hypogaea L.) in Iran. ARPN J. Agric. Biol. Sci., 7, 289-293.

Morsy, S.M.A. (1999). Pathological studies on rootrot of peanut in Egypt. Ph.D. Thesis, Faculty of Agriculture, Suez Canal Univ., Egypt.

Morsy, S.M.A. (2013). Effect of soil texture and irrigation water quality on peanut seedling infection with Rhizoctonia solani. Egypt. J. Phytopathol., 41, $1-12$.

Rafi, H., Dawar, S. and Tariq, M. (2016). Combined effect of soil amendment with oil cakes and seed priming in the control of root rot fungi of leguminous and non-leguminous crops. Pak. J. Bot., 48, 1305-1311.

Rao, K. T., Rao, A. U., and Sekher, D. (2013). Effect of sources and levels of sulfur on groundnut. J. Acad. Ind. Res., 2, 268-270.

Sakr, M.T., Mohamed, Z.A., El- Emery, M.I. and AboEl-Dahab, M.S. (2010). Alleviating the harmful effect of some soilborne fungi in wheat plant grown under infected soil with Fusarium graminearum or Bipolaris sorokiniana. J. Plant Prod., 1, 11-25.

SAS (1996). Software program. Cary, North Carolina State. Univ., Karl M Glsener. USA.

Snedecor, G.W. (1956). Statistical Methods. Fifth edition. Ames, Iowa, the Iowa State Univ. Press.

Tolpa, S., Kukla, S. and Noga, H. (1976). Control of the downy mildew of onion (Peronospora destructor

Env. Biodiv. Soil Security Vol.1 (2017) 
[Berk.] Casp.) with the acid of preparations derivating from peat. Roczn Nauk Roln, 2, 239-251.

Walker, M.E. and Csinos, A.S. (1980). Effect of gypsum on yield, grade and incidence of pod-rot in five peanut cultivars. Peanut Sci., 7, 109-113.

(Received 9/10/2017;

accepted 20/11/2017) 